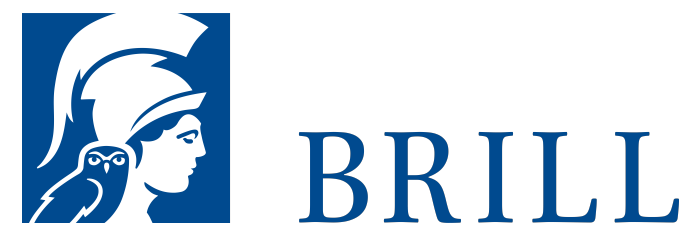

\title{
Mass Atrocities, Risk and Resilience
}

\section{Rethinking Prevention}

Editor: Stephen McLoughlin

Mass Atrocities, Risk and Resilience examines the relationship between risk and resilience in the prevention of genocide and other mass atrocities and explores two broad areas of neglect. In terms of prevention, there is very little research that analyzes how local and national actors manage the risk associated with mass atrocities. In the field of comparative genocide studies, to date there has been very little interest in examining negative cases. Although much is known about why mass atrocities occur, much less is established about why they do not occur. The contributions in this book address this neglect in two important ways. First, they challenge commonly-accepted approaches to prevention. Second, they explore negative cases in order to better understand how local and national actors have mitigated risk over time.

Readership

- Scholars - political scientists, particularly those specializing in civil war, genocide and mass political violence

- Policy makers/practitioners - especially those working in the field of conflict/mass atrocities prevention and conflict resolution in the United Nations, and international NGOs, such as International Crisis Group, Oxfam and the Carter Center. - Students of political science, particularly in the areas of comparative genocide studies and peace and conflict studies.

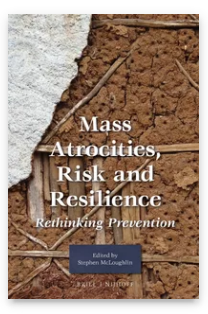

Pages: $\mathrm{x}, 237 \mathrm{pp}$.

Language:

English

Subjects:

Humanitarian

Law, Human

Rights and

Humanitarian

Law, Human

Rights, Human

Rights and

Humanitarian

Law

Publisher: Brill | Nijhoff

E-Book (PDF)

Released online: 29Jun 2015

ISBN: 978-9004-29987-O

List price

USD $\$ 107.00$

Paperback

Publication date:

o3 Jul 2015

ISBN: 978-90-

O4-29986-3

List price

USD $\$ 105.00$ 
Stephen McLoughlin is a Research Fellow at the Griffith Asia Institute and Centre for Governance and Public Policy, at Griffith University. His research interests include mass atrocities early warning, structural prevention of mass atrocities, ethnic conflict in post-communist states, and the responsibility to protect. His current research is focused on understanding local and national sources of resilience, and how these play a protective role in states at risk of future atrocities. He is the author of the recent book The Structural Prevention of Mass Atrocities: Understanding Risk and Resilience.

For more information see brill.com

Order information: Order online at brill.com +44330 3330049 | customerservices@brill.com Submission information: brill.com/authors

Titles published by Brill | Fink, Brill | mentis or Brill | Schöningh: +49(o)71 5413279216 | brill@brocom.de 